\title{
REACTIONS OF A TRANS-DIAMMINEDIAQUAPLATINUM(II) COMPLEX WITH L-CYSTEINE
}

\author{
Sutopo Hadi ${ }^{1}$, Bambang Irawan ${ }^{2}$, Noviany Noviany ${ }^{1}$, Yandri Yandri ${ }^{1}$, Tati Suhartati ${ }^{1}$ \\ ${ }^{1}$ Department of Chemistry, Universitas Lampung, Bandar Lampung, 35145 Indonesia \\ ${ }^{2}$ Department of Biology, Universitas Lampung, Bandar Lampung, 35145 Indonesia \\ sutopo.hadi@ fmipa.unila.ac.id
}

\begin{abstract}
The reaction of a trans-diamminediaquaplatinum(II) complex, trans- $\left[\mathrm{Pt}\left({ }^{15} \mathrm{NH}_{3}\right)_{2}\left(\mathrm{H}_{2} \mathrm{O}\right)_{2}\right]^{2+}(\mathbf{1})$, and $\mathrm{L}$-cysteine ( $\mathrm{R}-\mathrm{SH})$ has been performed to confirm the formation of the products in the solution. The reaction was monitored by $1-\mathrm{D}{ }^{15} \mathrm{~N}$ and 2-D $\left[{ }^{1} \mathrm{H},{ }^{15} \mathrm{~N}\right]$ heteronuclear single-quantum coherence (HSQC) Nuclear Magnetic Resonance (NMR) and electrospray ionization (ESI) mass spectrometry. The reaction was initially performed in an alkaline solution; the platinum mononuclear species products were observed. The $\mathrm{pH}$ of the solution was then decreased to an acidic solution; the products obtained were oligomeric platinum products. Based on the spectrum from mass spectrometry, which was obtained in a basic solution, the most dominant complex in the solution is a dinuclear platinum(II) species with a sulfur-bridging, trans-[\{Pt $\left.(\mathrm{S} \text {-cys })_{2}\left({ }^{15} \mathrm{NH}_{3}\right)_{2}\right\}_{2}(\mathrm{~S}$-cys $\left.)\right]^{+}$having $\mathrm{m} / \mathrm{z}$ of 822 . The loss of two successive ammines was observed.
\end{abstract}

Keywords: 2-D NMR; L-cysteine; oligomers; thiolate

\section{РЕАКЦИИ НА КОМПЛЕКСОТ TRANS-ДИАМИНДИАКВАПЛАТИНА(II) CO L-ЦИСТЕИН}

Извршена е реакција на комплексот trans-диаминдиакваплатина(II), trans-[Pt( $\left.\left({ }^{15} \mathrm{NH}_{3}\right)_{2}\left(\mathrm{H}_{2} \mathrm{O}\right)_{2}\right]^{2+}$ (1), co L-цистеин (R-SH) за да се потврди образувањето на продукти во раствор. Реакцијата беше следена со $1-\mathrm{D}{ }^{15} \mathrm{~N}$ и $2-\mathrm{D}\left[{ }^{1} \mathrm{H},{ }^{15} \mathrm{~N}\right]$ хетеронуклеарна едноквантна кохерентна (HSQC) NMR и со масен спектрометар со електронспрејна јонизација (ESI). Првично реакцијата беше изведена во алкална средина, при што беа забележани мононуклеарни видови платина. Потоа $\mathrm{pH}$ на растворот беше намален до кисела средина, при што беа добиени олигомерни производи на платина. Врз основа на спектарот од масена спкетрометрија што беше добиен во базна средина, најзастапениот комплекс во растворот е динуклеарен вид на платина(II) со мост од сулфур, trans-[\{Pt(Scys $\left.)_{2}\left({ }^{15} \mathrm{NH}_{3}\right)_{2}\right\}_{2}(S \text {-cys) }]^{+}$со $\mathrm{m} / z$ од 822 , а беше забележано губење на два последователни амина.

Клучни зборови: 2-D NMR; L-цистеин; олигоемри; тиолат

\section{INTRODUCTION}

Platinum-based chemotherapeutic drugs, such as cisplatin and carboplatin, are still of interest due to their wide applications for the treatment of various types of tumors [1]. A large number of $\mathrm{Pt}(\mathrm{II})$ and $\mathrm{Pt}(\mathrm{IV})$ complexes have been prepared in order to improve their applicability in the treatment of cancers [2-4]. Some new compounds, such as phenanthriplatin [2] and trans-bis(2-phenylselenyl-
methyl)oxolane)dichloroplatinum(II) [3] complexes, have recently been synthesized and reported to enrich the new potent platinum drugs used in the treatment of cancers.

The monoaquated and diaquated species of cisplatin are key intermediates in the mechanism responsible for the antitumor activity of cisplatin. Its inactive isomer, transplatin, was also reacted through the formation of these aquated species [5]. Furthermore, the interactions of cisplatin, cis- 
$\left[\operatorname{Pt}\left({ }^{15} \mathrm{NH}_{3}\right)_{2} \mathrm{Cl}_{2}\right]$, and its hydrolytes, with thiol ligands, i.e. ligands having sulfur donor, have been extensively studied [6-9]. Conversely, the reactions of the trans analog have been less reported since transplatin, trans-diamminedichloroplatinum(II), trans- $\left[\mathrm{Pt}\left({ }^{15} \mathrm{NH}_{3}\right)_{2} \mathrm{Cl}_{2}\right]$ complexes are known to not show antitumor activity [10-12]. There is interest in the reactions of platinum(II) complexes with ligands having a sulfur donor because it is believed that before reaching the DNA, the platinum(II) complexes will bind to the cell constituents that contain ligands having sulfur as the donor $[8,13,14]$.

The reactions of platinum(II) complexes with glutathione and acetylcysteine, two examples of ligands containing sulfur, have previously been studied, and the results indicated that the $\mathrm{pH}$ of the reactions influenced the products obtained in the reactions $[12,15,16]$. In these kinds of reactions, if the $\mathrm{pH}$ condition was less than 7 , the thiol group bridging the two platinum centers was the main coordination mode observed, whereas when the reaction was performed at a $\mathrm{pH}$ greater than 7 , the main product observed was a mononuclear platinum complex. This condition is caused by the fact that at $\mathrm{pH}<7$, the proton is still attached to the thiol group so that the ligand will be able to coordinate easily. When a thiol is already coordinated to the metal, it can still act as a nucleophile; thus, the reaction performed at a lower $\mathrm{pH}$ will make the second metal likely to bind with this coordinated thiol, and therefore, a bridge species can be formed. Upon increasing the $\mathrm{pH}$ of the reaction to $\sim 10$, most of the thiols are deprotonated; thus, the preferred product will be a non-bridging platinum complex $[9,17]$.

A similar observation was also found in the reaction of $c i s-\left[\mathrm{Pt}\left({ }^{15} \mathrm{NH}_{3}\right)_{2}\left(\mathrm{H}_{2} \mathrm{O}\right)_{2}\right]^{2+}$, the second hydrolyte of cisplatin, with thiols at low $\mathrm{pH}$ at a concentration of $\sim 0.1 \mathrm{M}$; the products observed were involved in the formation of a complex having sulfur bridges, as a thiolate is known to form more bridge species at a lower $\mathrm{pH}$ than at a higher $\mathrm{pH}$ [1]. This phenomenon will also be useful for the characterization of the interesting products observed in this work. In this work, the reaction of trans$\left[\mathrm{Pt}\left({ }^{15} \mathrm{NH}_{3}\right)_{2}\left(\mathrm{H}_{2} \mathrm{O}\right)_{2}\right]^{2+}$ and an amino acid containing a sulfur donor, L-cysteine (R-SH), is reported.

\section{EXPERIMENTAL}

\subsection{Materials}

The preparation of trans- $\left[\mathrm{Pt}\left({ }^{15} \mathrm{NH}_{3}\right)_{2}\left(\mathrm{NO}_{3}\right)_{2}\right]$ was based on the procedure available in the literature [13]. L-cysteine (R-SH) was obtained from Sigma-
Aldrich Chemical Company, and $\left({ }^{15} \mathrm{NH}_{4}\right)_{2} \mathrm{SO}_{4}(99 \%$ ${ }^{15} \mathrm{~N}$, Cambridge Isotopes) was obtained from Novachem, Melbourne, Australia. They were used as received without further purification.

\subsection{Preparation of trans- $\left[\mathrm{Pt}\left({ }^{15} \mathrm{NH}_{3}\right)_{2}\left(\mathrm{H}_{2} \mathrm{O}\right)_{2}\right]^{2+}$}

The conversion of trans- $\left[\mathrm{Pt}\left({ }^{15} \mathrm{NH}_{3}\right)_{2}\left(\mathrm{NO}_{3}\right)_{2}\right]$ to trans- $\left[\mathrm{Pt}\left({ }^{15} \mathrm{NH}_{3}\right)_{2}\left(\mathrm{H}_{2} \mathrm{O}\right)_{2}\right]^{2+}(\mathbf{1})$ in an aqueous solution was performed using the following procedure: $17.75 \mathrm{mg}$ of trans-[Pt( $\left.\left.{ }^{15} \mathrm{NH}_{3}\right)_{2}\left(\mathrm{NO}_{3}\right)_{2}\right]$ was placed in a small bottle. Then, it was dissolved with $10 \mathrm{ml}$ of water, and the solution was warmed at 37 ${ }^{\circ} \mathrm{C}$ for $\sim 30 \mathrm{~min}$. The $\mathrm{pH}$ of this solution was adjusted to an acidic condition by the addition of $0.1 \mathrm{M}$ nitric acid. Gravity filtration was performed to remove any remaining solids. The filtrate containing a solution of trans- $\left[\mathrm{Pt}\left({ }^{15} \mathrm{NH}_{3}\right)_{2}\left(\mathrm{H}_{2} \mathrm{O}\right)_{2}\right]\left(\mathrm{NO}_{3}\right)_{2}(\mathbf{1})$ with a concentration of $5 \mathrm{mM}$ was then checked with 1D ${ }^{15} \mathrm{~N}$ NMR. A solution of $\mathbf{1}$ with a concentration of $1 \mathrm{mM}$ was prepared by diluting the $5 \mathrm{mM}$ stock solution of $\mathbf{1}$.

\subsection{Reaction of trans- $\left[\mathrm{Pt}\left({ }^{15} \mathrm{NH}_{3}\right)_{2}\left(\mathrm{H}_{2} \mathrm{O}\right)_{2}\right]^{2+}(\mathbf{1})$ with L-cysteine}

The reaction of $\mathbf{1}$ with the amino acid, Lcysteine ( $\mathrm{R}-\mathrm{SH})$, was followed and monitored routinely with 2-D $\left[{ }^{1} \mathrm{H},{ }^{15} \mathrm{~N}\right] \mathrm{HSQC}$ NMR. The following procedure was performed: $0.122 \mathrm{mg}$ ( $1 \mathrm{mmol}$ ) of $\mathrm{R}-\mathrm{SH}$ was placed in a small bottle, and then $0.5 \mathrm{ml}$ of a $1 \mathrm{mM}$ solution of 1 $(0.5 \mathrm{mmol})$ was added. The adjustment of $\mathrm{pH}$ was done by the addition of nitric acid and sodium hydroxide to reach a $\mathrm{pH}$ of $\sim 2.0$. To minimize the oxidation of $\mathrm{R}-\mathrm{SH}$, the process was performed under argon gas. The measurement was then taken using a similar procedure that was previously published $[12,19]$.

\subsection{NMR measurements}

One-dimensional $\quad 40.54 \mathrm{MHz} \quad{ }^{15} \mathrm{~N} \quad \mathrm{NMR}$ spectra were recorded with a Bruker Avance 400 $\mathrm{MHz}$ spectrometer with a $5 \mathrm{~mm}$ broadband multinuclear probe. The sensitivity of the ${ }^{15} \mathrm{~N}$ NMR measurement was increased by the use of the Distortionless Enhancement by Polarization Transfer (DEPT) pulse sequence [10]. To obtain a good spectrum, the number of scans used was between 250 and 500 . The recycle time used was $3.54 \mathrm{~s}$, and the pulse width was $12.55 \mu \mathrm{s}$; hence, a tilt angle of $45^{\circ}$ was applied. The number of data points used was $32 \mathrm{~K}$. Chemical shifts are reported relative to $2.5 \mathrm{M} \quad\left({ }^{15} \mathrm{NH}_{4}\right)_{2} \mathrm{SO}_{4}$ in $1 \mathrm{M} \quad \mathrm{H}_{2} \mathrm{SO}_{4}$ $\left(\delta_{\mathrm{N}}=0.00\right)$ in a coaxial capillary. The 2-D $\left[{ }^{1} \mathrm{H}\right.$, 
$\left.{ }^{15} \mathrm{~N}\right]$ HSQC NMR spectra were obtained on a Bruker Avance $400 \mathrm{MHz}$ spectrometer $\left({ }^{1} \mathrm{H}\right.$, $400.1 \mathrm{MHz} ;{ }^{15} \mathrm{~N}, 40.54 \mathrm{MHz}$ ) using the sequence available in the literature $[20,21]$.

\subsection{Electrospray ionization mass spectrometry $(E S I-M S)$}

The method used to prepare the sample for ESI-MS was as follows: $0.61 \mathrm{mg}(5 \mathrm{mmol})$ of $\mathrm{R}-$ SH was taken and added to a small bottle containing $0.5 \mathrm{ml} 5 \mathrm{mM}(2.5 \mathrm{mmol})$ of solution 1 . The $\mathrm{pH}$ was adjusted with $0.1 \mathrm{M}$ nitric acid to $\sim 2.0$ under argon gas. To minimize the oxidation of $\mathrm{R}-\mathrm{SH}$, the bottle was then sealed with parafilm. The mole ratio of $\mathrm{R}-\mathrm{SH}$ and complex $\mathbf{1}$ was $2: 1$. After the reaction mixture was left for $45 \min$ to $1 \mathrm{~h}$, the ESI-MS spectrum of this reaction was taken.

\section{RESULTS AND DISCUSSION}

Two-dimensional $\left[{ }^{1} \mathrm{H},{ }^{15} \mathrm{~N}\right]$ NMR has been used to follow and monitor the product observed in the reaction of 1 with $\mathrm{R}-\mathrm{SH}$. The initial reaction was started with a $1 \mathrm{mM}$ concentration of $\mathbf{1}$, and the mole ratio used between 1 and $\mathrm{R}-\mathrm{SH}$ was 1:2. Based on the spectra recorded, the products observed in the reaction of $\mathbf{1}$ with $\mathrm{R}-\mathrm{SH}$ were similar to those of trans- $\left[\mathrm{Pt}\left({ }^{15} \mathrm{NH}_{3}\right)_{2}\left(\mathrm{H}_{2} \mathrm{O}\right)_{2}\right]^{2+}$ with glutathione [12] and $\mathrm{H}_{3}$ accys [19]. Figure 1 summarizes the reactions that occurred in both acidic and basic conditions, and they were based on the spectra recorded, as shown in Figures 2-4.

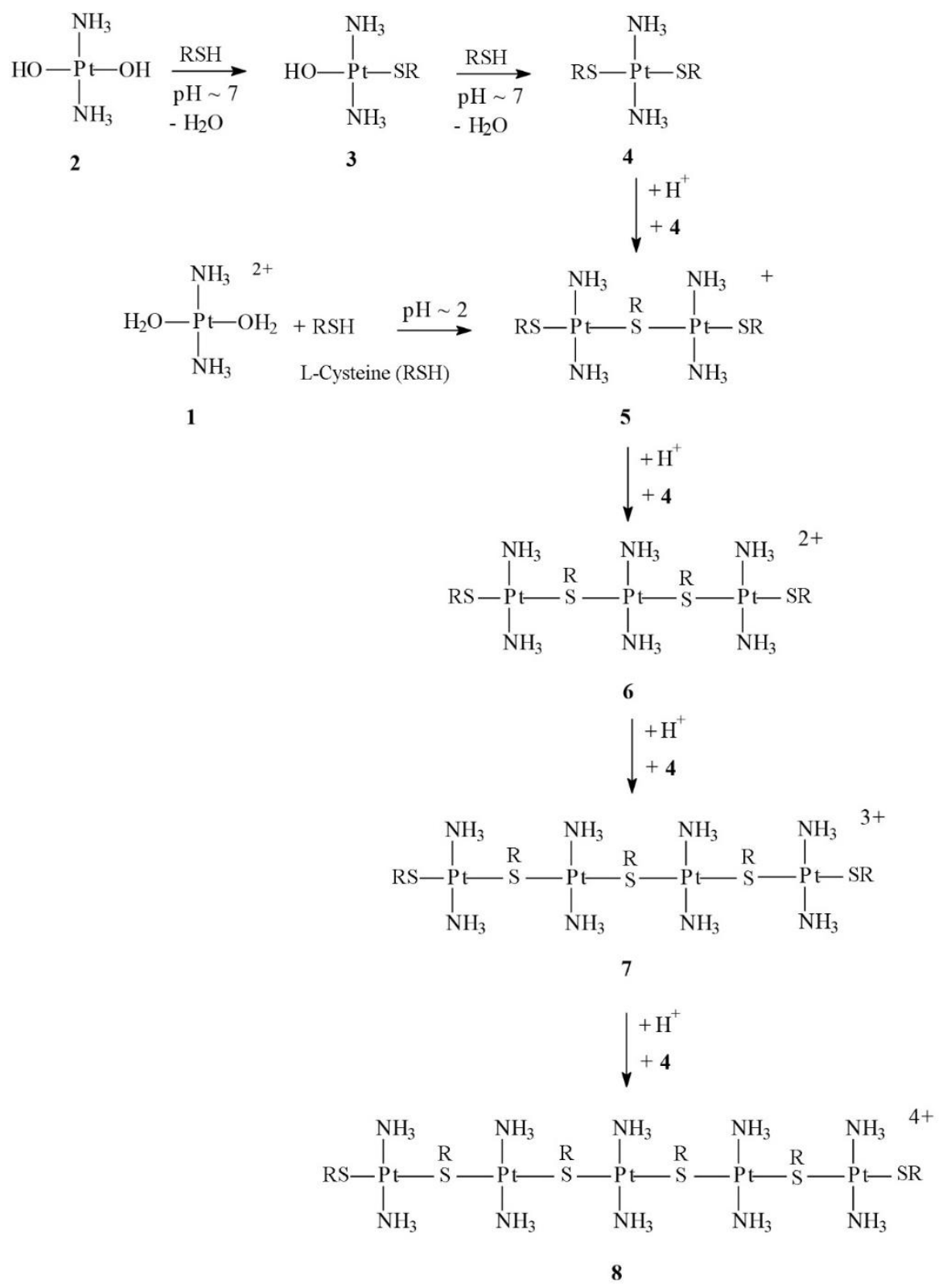

Fig. 1. The schematic reaction of complex 1 with L-cysteine (R-SH) in basic and acidic solutions 
Figure 2 shows the spectrum obtained for the initial reaction that was performed at a basic condition $(\mathrm{pH}>7)$. There are some peaks observed in this spectrum. The first peak was at $\delta_{\mathrm{N}} / \delta_{\mathrm{H}}$ $-62.61 / 3.69 \mathrm{ppm}$, and it was due to the presence of trans-[Pt $\left.(\mathrm{OH})_{2}\left({ }^{15} \mathrm{NH}_{3}\right)_{2}\right]$ (2). There were two new peaks present, namely at $\delta_{\mathrm{N}} / \delta_{\mathrm{H}}-59.28 / 3.79 \mathrm{ppm}$ labeled as $\mathbf{A}$ and at $\delta_{\mathrm{N}} / \delta_{\mathrm{H}}-63.46 / 3.49 \mathrm{ppm}$ labeled as $\mathbf{B}$, where peak $\mathbf{B}$ was slightly more intense. These peaks did not change after the solution containing compounds, labeled $\mathbf{A}$ and $\mathbf{B}$ were left for some time in the reaction mixture. As mentioned above, the formation of bridge species is not preferable at higher $\mathrm{pH}[6,9,15,22]$; thus, the complex labeled $\mathbf{A}$ was assigned as trans$\left[\mathrm{Pt}(\mathrm{OH})(\mathrm{SR})\left({ }^{15} \mathrm{NH}_{3}\right)_{2}\right]$ (3) and that labeled $\mathbf{B}$ as trans-[Pt $\left.(\mathrm{SR})_{2}\left({ }^{15} \mathrm{NH}_{3}\right)_{2}\right]$ (4). This analysis is based on the NMR spectra obtained in Figures 2 and 3. The NMR spectrum in Figure 2 represents the reaction that was performed at a higher $\mathrm{pH}$; hence, complex $\mathbf{3}$ was the main complex present in the reaction mixture. The NMR spectrum in Figure 3 was run at a lower $\mathrm{pH}$ than the first reaction (Fig. $2)$; therefore, complex $\mathbf{3}$ would be less expected in the reaction.

The ${ }^{15} \mathrm{~N}$ chemical shifts for $\mathbf{3}$ and $\mathbf{4}$ are at the same region, whereas in the proton NMR, their chemical shifts are very different. The product formation observed in these two reactions is almost the same in terms of molecular structure with those reported by other works [12, 19, 23]. Upon decreasing the $\mathrm{pH}$ of the reaction to $\sim 2$, the two peaks $\mathbf{A}$ and $\mathbf{B}$ were diminished, and four new peaks appeared and were observed by 2-D NMR in the mixture reactions. The strongest peaks were labeled as $\mathbf{C}, \mathbf{D}, \mathbf{E}$, and $\mathbf{F}$. These peaks were also observed when the reactions of $\mathbf{1}$ and $\mathrm{R}-\mathrm{SH}$ were performed in an acidic condition, as in the following discussion.

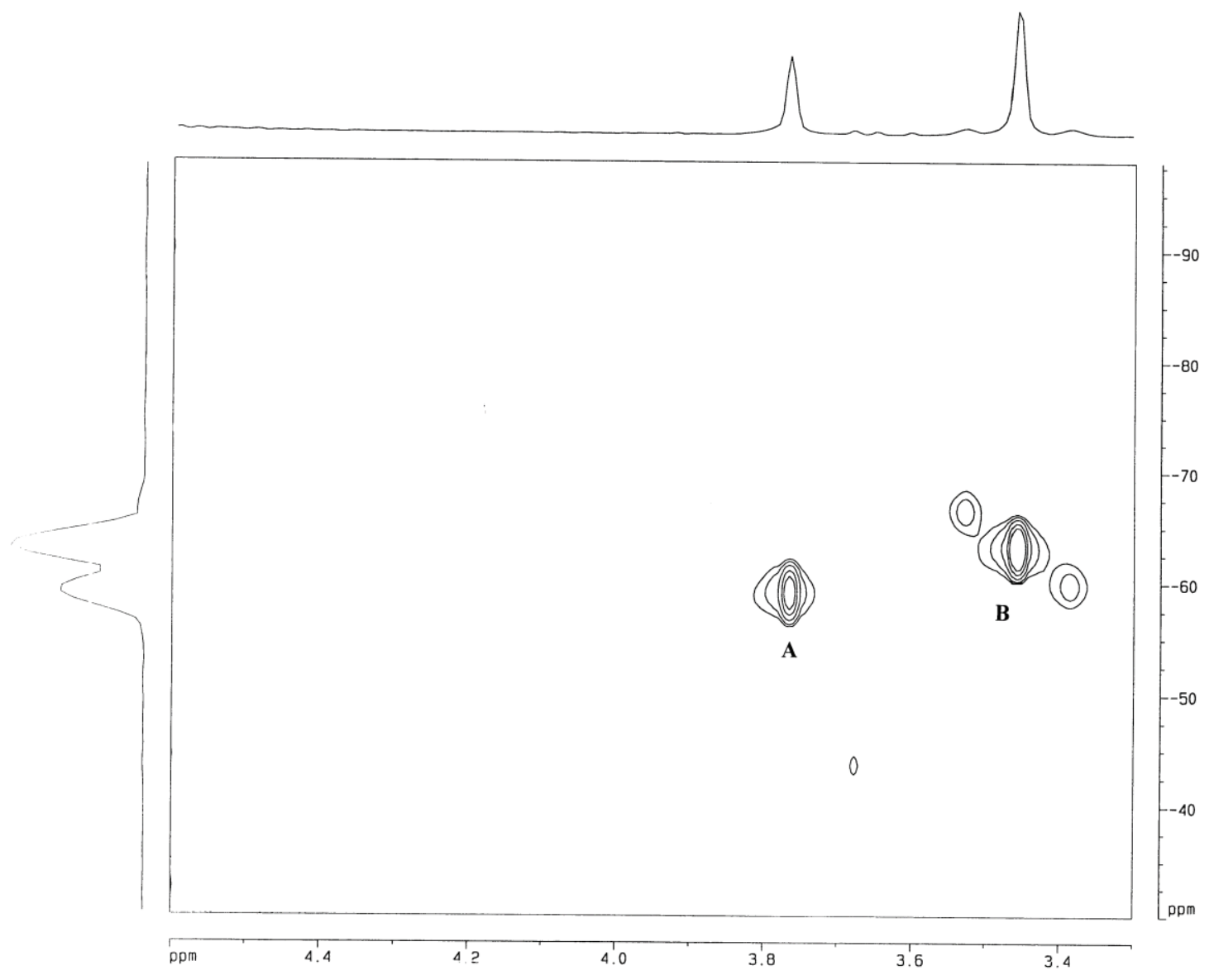

Fig. 2. 2D NMR spectrum from the reaction of $1 \mathrm{mM}(\mathbf{1})$ and $\mathrm{R}-\mathrm{SH}$ in a 1:2 mol ratio measured at a basic condition and recorded $1 \mathrm{~h}$ after the reaction. 


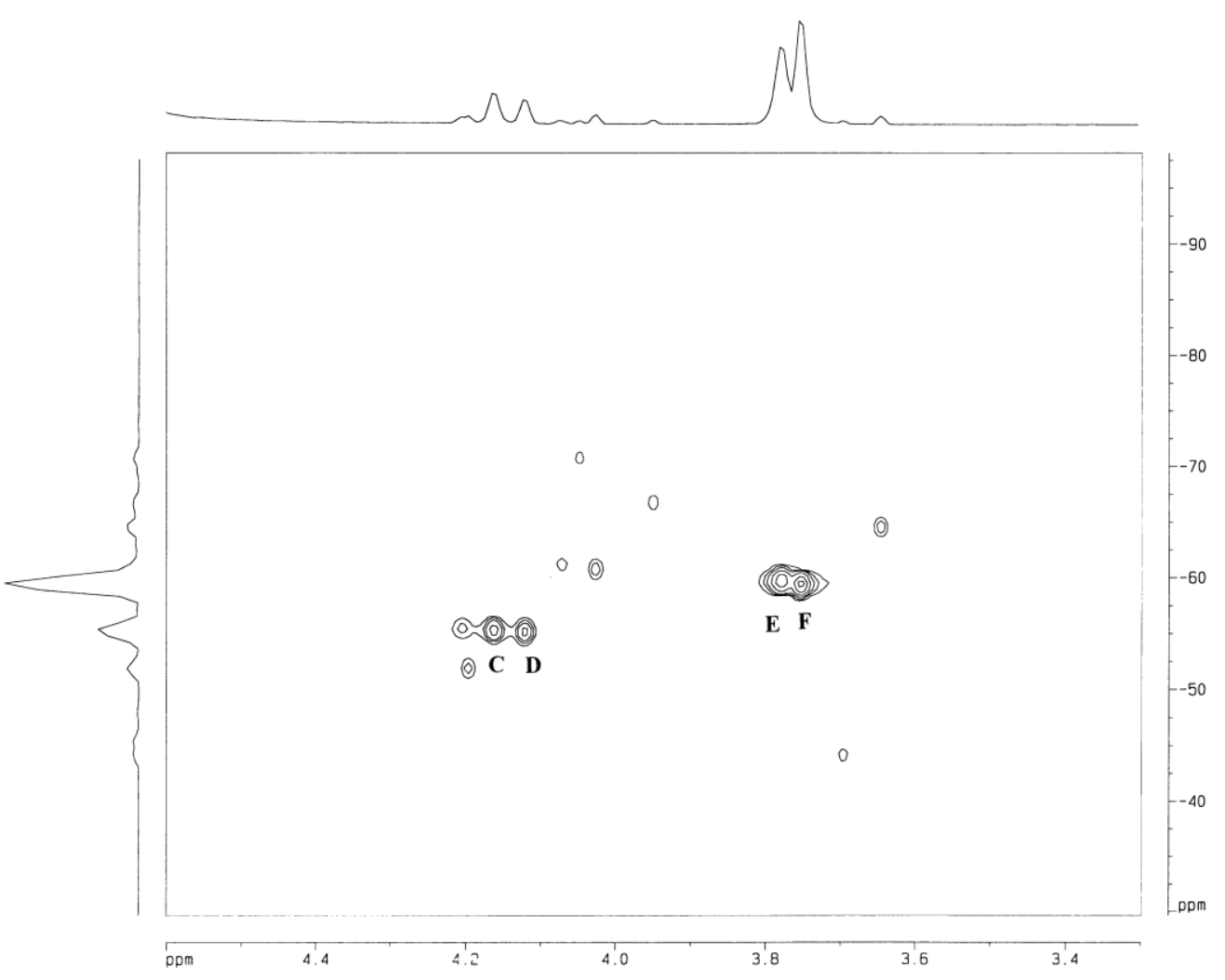

Fig. 3. 2D NMR spectrum from the reaction of $1 \mathrm{mM}(\mathbf{1})$ and R-SH in a 1:2 mol ratio at an acidic condition obtained $30 \mathrm{~h}$ after the reaction has started.

The reaction of complex 1 and L-cysteine was then performed at an acidic solution with a $\mathrm{pH}$ of $\sim 2$. One hour after the reaction commenced, there were four new major peaks observed in the 2-D NMR spectrum (Fig. 4) beside the peak of 1 with a chemical shift of $\delta_{\mathrm{N}} / \delta_{\mathrm{H}}-62.41 / 4.10 \mathrm{ppm}$. These four new peaks were labeled as $\mathbf{C}, \mathbf{D}, \mathbf{E}$, and $\mathbf{F}$ with chemical shifts of $\delta_{\mathrm{N}} / \delta_{\mathrm{H}}-55.57 / 4.19 \mathrm{ppm}, \delta_{\mathrm{N}} / \delta_{\mathrm{H}}$ $-55.95 / 4.15 \mathrm{ppm}, \delta_{\mathrm{N}} / \delta_{\mathrm{H}}-60.25 / 3.80 \mathrm{ppm}$, and $\delta_{\mathrm{N}} / \delta_{\mathrm{H}}$ $-59.56 / 3.76 \mathrm{ppm}$, respectively. Surprisingly, these peaks still remained in the solution even after $30 \mathrm{~h}$ of reaction. These observations were similar to the reaction that was performed initially at a basic condition and then was acidified. When the $\mathrm{pH}$ of this reaction was increased to $\sim 7$, these four peaks diminished from the spectrum, and two new peaks appeared in the spectrum. These two peaks were exactly the same as the peaks labeled $\mathbf{A}$ and $\mathbf{B}$, which have been observed from the mixture at higher $\mathrm{pH}$, as shown in Figure 2b. Thus, the peaks observed from reaction $\mathbf{1}$ in an acidic condition are assigned as platinum complexes bridge to sulfur. Furthermore, in this reaction, it would be possible for the platinum complexes to have dinuclear species and up to pentanuclear species.

The formation of platinum complex $\mathbf{5}$, which is dinuclear, in the spectrum will only have a single peak with a chemical shift of $\delta_{\mathrm{N}} / \delta_{\mathrm{H}}-60.3 / 3.74 \mathrm{ppm}$, representing the signal for the diammineplatinum, $\left(\mathrm{Pt}\left(\mathrm{NH}_{3}\right)_{2}\right)$, terminal. For complex 6, which is trinuclear, the platinum complex will show two peaks in the spectrum, namely, one from the diammineplatinum terminal and the other from the internal diammineplatinum with a chemical shift of $\delta_{\mathrm{N}} / \delta_{\mathrm{H}}$ $-55.3 / 4.2 \mathrm{ppm}$, in which the intensity ratio for these two peaks is $2: 1$. When platinum tetranuclear 7 is formed in the reaction mixture, two signals were also observed, but in this complex, the peak intensity ratio between the terminal and internal diammineplatinum would be $1: 1$. The last possibility is the formation of platinum pentanuclear complex $\mathbf{8}$, which will give rise to three peaks, namely, one from the terminal and two different peaks from the internal diammineplatinum with an intensity ratio of 2:2:1. The spectrum in Figure 3 indicated that in the region for the terminal diammineplatinum, the labeled peaks $\mathbf{E}$ and $\mathbf{F}$ were poor, so they were not resolved clearly, whereas the signal for the internal peaks (labeled $\mathbf{C}$ and $\mathbf{D}$ ) were observed to be more intense, so they were clearly resolved. The present four labeled peaks $\mathbf{C}, \mathbf{D}, \mathbf{E}$, and $\mathbf{F}$ in this spectrum were indications that the oligomer complexes up to a pentanuclear platinum complex had been formed in the mixture reaction. 


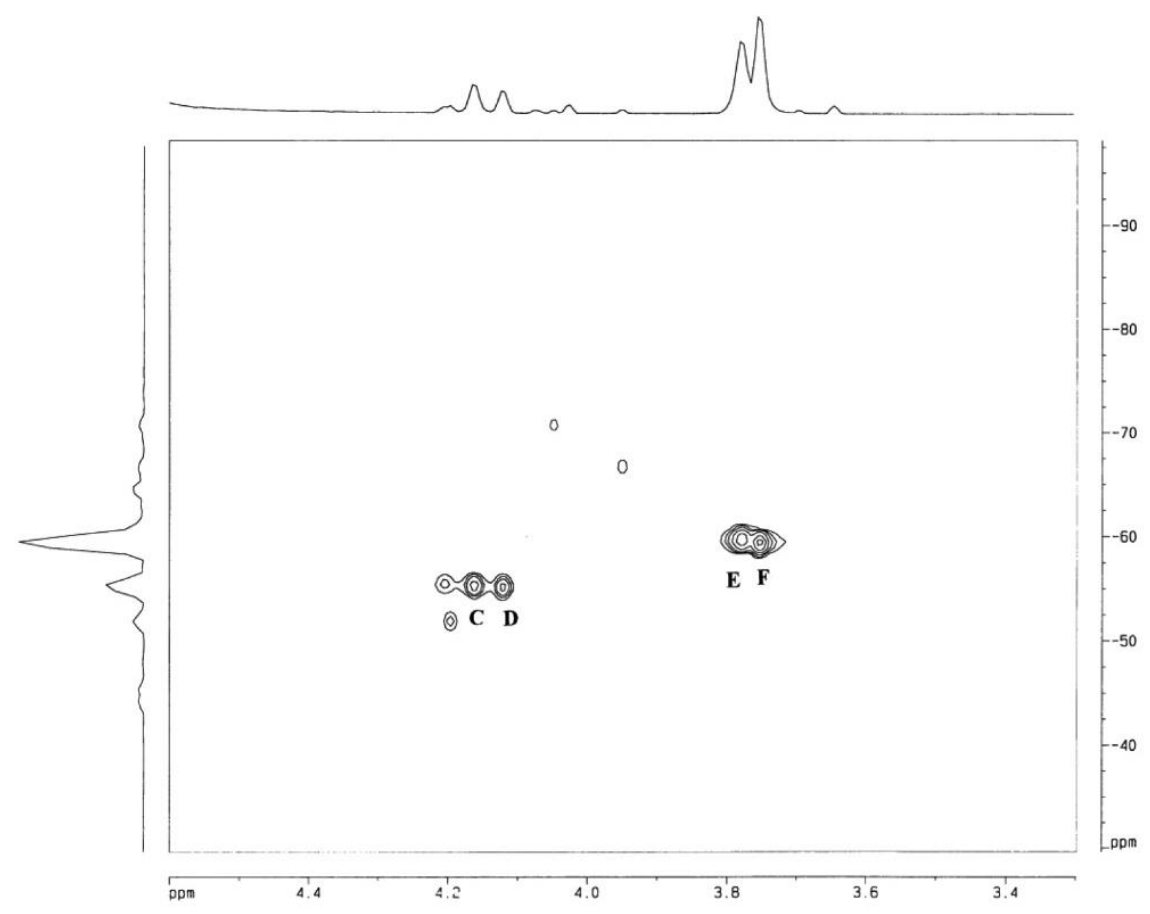

Fig. 4. 2D NMR spectrum from the reaction of $1 \mathrm{mM}(\mathbf{1})$ and $\mathrm{R}-\mathrm{SH}$ in a 1:2 mol ratio at an acidic condition obtained $30 \mathrm{~h}$ after the reaction has started

Based on the ESI-MS spectrum recorded at $\mathrm{pH} \sim 2$ (Fig. 5), complex 5 showed the strongest peak with $\mathrm{m} / \mathrm{z}$ of 822 . Based on the separation of the isotope lines, this complex has a charge of +1 . The spectrum also gave information about the isotope pattern of the compounds in the mixture reaction, and as expected, the spectrum obtained is an indication to the presence for two platinum atoms pattern. The observed product of the reactions has structures similar to the products obtained in the reaction of 1 with N-acetyl-L-cysteine [19] and glutathione [12]. There were two other peaks observed with $\mathrm{m} / \mathrm{z}$ of 786 and 750 , which indicates a difference of 36 amu between the major peak and

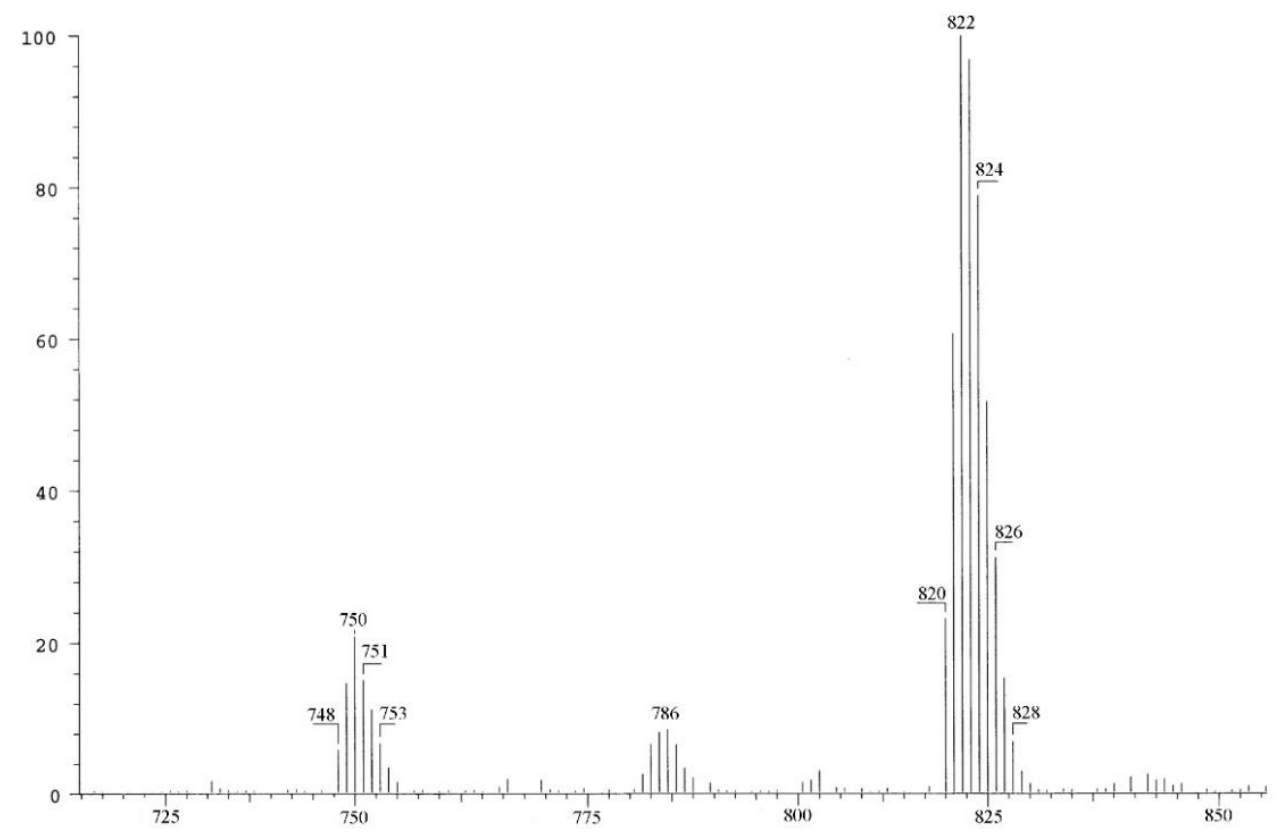

Fig. 5. ESI-MS spectrum from the reaction of $\mathbf{1}\left(5 \times 10^{-3} \mathrm{M}\right)$ and R-SH in a 1:2 mol ratio obtained $60 \mathrm{~min}$ after the reaction 
the others. The presence of the last two peaks was due to successive losses of two ammine ligands (the atomic mass unit of ${ }^{15} \mathrm{NH}_{3}$ was 18). Upon increasing the $\mathrm{pH}$ of the reaction to $\sim 7$, no peak was observed. This is likely because at higher $\mathrm{pH}$, the platinum complexes formed were neutral or have a negative charge.

\section{CONCLUSION}

The products observed from the reaction in this work generally have a molecular structure similar to the result of other studies in the reaction of cis- and trans-diamminediaquaplatinum(II) complexes with thiols, where in acidic conditions, the complexes observed involved platinum-sulfurbridged complexes, whereas in basic conditions, a mononuclear platinum complex was formed.

Acknowledgments. The authors thank the Universitas Lampung for the financial support given to carry out this work. We also thank Ms. L. Lambert for helping us conduct the NMR work and Mr. G. McFarlane for his help in obtaining the ESI-MS spectrum. A special thanks and dedication is given to the late Prof. Trevor G. Appleton, University of Queensland, who was deceased on June 12, 2013, for giving SH previous experiences on ${ }^{15} \mathrm{~N}$ both 1D and 2D NMR. We would also like to thank Enago (www.enago.com) for the English language proofreading and review.

\section{REFERENCES}

[1] E. Shail, Platinum anticancer drugs and photochemotherapeutic agents: recent advances and future developments, Sci. Prog. 97, 20-40 (2014).

DOI:https://doi.org/10.3184/003685014X13904811808460

[2] N. Radenković, M. D. Kostić, N. Z. Đorđević, Z. C. Dolicanin, T. V. Soldatović, M. N. Živanović, V. M. Divac, Synthesis of new $\mathrm{Pt}(\mathrm{II})$ complex bearing organoselenium ligands and evaluation of cytotoxic activity of some structurally related Pd(II) complexes, Maced. $J$. Chem. Chem. Eng. 39, 59-64 (2020).

DOI: https://doi.org/10.20450/mjcce.2020.1905

[3] G. Y. Park, J. J. Wilson, Y. Song, S. J. Lippard, Phenanthriplatin, a monofunctional DNA-binding platinum anticancer drug candidate with unusual potency and cellular activity profile, Proc. Natl. Acad. Sci. U.S.A. 109, 11987-11992 (2012).

DOI: https://doi.org/10.1073/pnas.1207670109

[4] M. D. Veclani, A. Melchior, M. Tolazzi, J. P. CeronCarrasco, Using theory to reinterpret the kinetics of monofunctional platinum anticancer drugs: stacking, $J$. Am. Chem. Soc. 140, 14024-14027 (2018).

DOI: https://doi.org/10.1021/jacs.8b07875

[5] D. Corinti, C. Coletti, N. Re, S. Piccirillo, M. Giampà, M. E. Crestoni, S. Fornarini, Hydrolysis of cis- and transplatin: structure and reactivity of the aqua complexes in a solvent free environment, $R S C A d v$. 7, 1587715884 (2017).

DOI: https://doi.org/10.1039/C7RA01182B
[6] T. G. Appleton, J. W. Connor, J. R. Hall, P. D. Prenzler, NMR study of the reactions of the cis-diamminediaquaplatinum(II) cation with glutathione and amino acids containing a thiol group, Inorg. Chem. 28, 20302037 (1989).

DOI: https://doi.org/ 10.1021/ic00310a007

[7] P. C. Dedon, R. F. Borch, Characterization of the reactions of platinum antitumor agents with biologic and nonbiologic sulfur-containing nucleophiles, Biochem. Pharmacol. 36,1955-1964 (1987). DOI: https://doi.org/ 10.1016/0006-2952(87)90494-1

[8] M. El-Khateeb, T. G. Appleton, L. R. Gahan, B. G. Charles, S. J. Berners-Price, A.M. Bolton, Reactions of cisplatin hydrolytes with methionine, cysteine, and plasma ultrafiltrate studied by a combination of HPLC and NMR techniques, J. Inorg. Biochem. 77, 13-21 (1999). DOI: https://doi.org/10.1016/s0162-0134(99)00146-4

[9] S. Hadi, T. G. Appleton, Reactions of cisplatin hydrolytes, cis- $\left[\mathrm{Pt}\left({ }^{15} \mathrm{NH}_{3}\right)_{2}\left(\mathrm{H}_{2} \mathrm{O}\right)_{2}\right]^{2+}$, with $\mathrm{N}$-acetyl-Lcysteine, Russ. J. Inorg. Chem. 55, 223-228 (2010). DOI: https://doi.org/10.1134/S0036023610020142

[10] S. J. Berners-Price, P. W. Kuchel, Reaction of cis- and trans-[ $\left.\mathrm{PtCl}_{2}\left(\mathrm{NH}_{3}\right)_{2}\right]$ with reduced glutathione inside human red blood cells, studied by ${ }^{1} \mathrm{H}$ and ${ }^{15} \mathrm{~N}-\left\{{ }^{1} \mathrm{H}\right\}$ DEPT NMR, J. Inorg. Biochem. 38, 327-345 (1990). DOI: https://doi.org/10.1016/0162-0134(90)80006-j

[11] M. Van Beusichem, N. Farrell, Activation of the trans geometry in platinum antitumor complexes. synthesis, characterization, and biological activity of complexes with the planar ligands pyridine, N-methylimidazole, thiazole, and quinoline. crystal and molecular structure of trans-dich, Inorg. Chem. 31, 634-639 (1992). DOI: https://doi.org/10.1021/ic00030a021

[12] S. Hadi, T. G. Appleton, Reactions of trans$\left[\mathrm{Pt}\left({ }^{15} \mathrm{NH}_{3}\right)_{2}\left(\mathrm{H}_{2} \mathrm{O}\right)_{2}\right]^{2+}$ with glutathione, Modern Appl. Sci. 2, 30-36 (2008).

DOI: https://doi.org/10.5539/mas.v2n6p30

[13] R. F. Borch, M. E. Pleasants, Inhibition of cis-platinum nephrotoxicity by diethyldithiocarbamate rescue in a rat model, Proc. Natl. Acad. Sci. U.S.A. 76, 6611-6614 (1979). DOI: https://doi.org/10.1073/pnas.76.12.6611

[14] D. L. Bodenner, P. C. Dedon, P. C. Keng, R. F. Borch, Effect of diethyldi-thiocarbamate on cis-Diamminedichloroplatinum(II)-induced cytotoxicity, DNA crosslinking, and $\gamma$-glutamyl transpeptidase inhibition, Cancer Res. 46, 2745-2750 (1986). PMID: 2870800

[15] E. L. M. Lempers, K. Inagaki, J. Reedijk, Reactions of $[\mathrm{PtCl}($ dien $)] \mathrm{Cl}$ with glutathione, oxidized glutathione and S-methyl glutathione. Formation of an S-bridged dinuclear unit, Inorg. Chim. Acta, 152, 201-207 (1988). DOI: https://doi.org/10.1016/S0020-1693(00)84952-X

[16] E. L. M. Lempers, J. Reedijk, Reversibility of binding of cisplatin-methionine in proteins by diethyldithiocarbamate or thiourea: a study with model adducts, Inorg. Chem. 29, 217-222 (1990).

DOI: https://doi.org/10.1021/ic00327a014

[17] S. Hadi, Reactions of The first cisplatin hydrolytes cis$\left[\mathrm{PtCl}\left({ }^{15} \mathrm{NH}_{3}\right)_{2}\left(\mathrm{H}_{2} \mathrm{O}\right)\right]^{+}$with $\mathrm{N}$-acetylcysteine, J. Mat. Sains, 11, 146-151 (2006).

[18] T. G. Appleton, A. J. Bailey, K. J. Baraham, J. R. Hall, Aspects of the solution chemistry of trans-diam- 
mineplatinum(II) complexes, Inorg. Chem. 31, 30773082 (1992).

DOI: https://doi.org/10.1021/ic00040a017

[19] S. Hadi, T. G. Appleton, Study of reaction of trans$\left[\mathrm{Pt}\left({ }^{15} \mathrm{NH}_{3}\right)_{2}\left(\mathrm{H}_{2} \mathrm{O}\right)_{2}\right]^{2+}$ with $\mathrm{N}$-acetyl-L-cysteine, Indo. J. Chem. 5, 54-57 (2005).

DOI: https://doi.org/10.22146/ijc.21839

[20] J. Stonehouse, G. L. Shaw, J. Keeler, E. D. Laue, Minimizing sensitivity losses in gradient-selected ${ }^{15} \mathrm{~N}-{ }^{1} \mathrm{H}$ HSQC spectra of proteins, J. Magn. Reson. Ser. A, 107, 178-184 (1994).

DOI: https://doi.org/10.1006/jmra.1994.1066
[21] S. Hadi, The reactions of tetramer platinum(IV) complexes, $\left[\left\{\mathrm{Pt}\left(\mathrm{CH}_{3}\right)_{2} \mathrm{X}_{2}\right\}_{4}\right],(\mathrm{X}=\mathrm{Cl}, \mathrm{Br}$, and I) with pyridine, Rev. Chim. 71, 230-235 (2020). DOI: https://doi.org/10.37358/RC.20.4.8061

[22] S. Hadi, T. G. Appleton, Reactions of the first cisplatin hydrolytes cis-[ $\left.\mathrm{PtCl}\left({ }^{15} \mathrm{NH}_{3}\right)_{2}\left(\mathrm{H}_{2} \mathrm{O}\right)\right]^{+}$with L-cysteine, Pol. J. Chem. 443, 437-443 (2009).

[23] M. E. Oehlsen, Y. Qu, N. Farrell, Reaction of polynuclear platinum antitumor compounds with reduced glutathione studied by multinuclear $\left({ }^{1} \mathrm{H},{ }^{1} \mathrm{H},-{ }^{15} \mathrm{~N}\right.$ gradient heteronuclear single-quantum coherence, and ${ }^{195} \mathrm{Pt}$ ) NMR spectroscopy, Inorg. Chem. 42, 5498-5506 (2003). DOI: https://doi.org/10.1021/ic030045b. 